歯科医に発症した非クロストリジウム性ガス壊疽の 1 例

\author{
産業医科大学第 1 外科 \\ 岡崎啓介松本健太郎岡本好司 \\ 小西鉄已永田直幹伊藤英明
}

職業との関連が示唆されるStreptococcus intermedius を起炎菌とするガス壇㾝の 1 例を経験した。症例は 42 歳, 男性, 雬科医. 薬剤アレルギー歴あり。2 週間前より特に 外傷なく右腋窝に疼痛と腫脹を生じ, 5 日前より同部の自潰排膿があり, 患者自ら歯科 診療所の器具を用い自潰部を縫合した，右腋裔および胸部の疼痛と発熱を主訴に来院。 来院時縫合部より出血および排膿がみられ，右腋窝および胸部の発赤熱発と触診上の握 雪感を認めた，炎症反応も強く，X線検査でも筋層内に気泡を認めたため，ガス壊疽と 診断し直ちに手術的にデブリードマン,ドレナージ施行。薬片リンパ球刺激試験で陰性 の抗生郕投与に加え高圧酸素療法も併用した。最終的に二次綘合し退院となった。本症 例で分離されたS. intermedius は, 以前はS. milleriグループに分類されており，口腔 内特に歯科領域で分離される.今回の症例では感染巣の增悪に関与したものと考えられ た.

卖引用語：非クロストリジウム性ガス壊疽，Streptococetrs intermedius，職業関連疾患

\section{緒言}

ガス壇疽の起炎菌となりうるガス産生性 Streptococcusとして知られるStreptococcus milleriは, 近 年, S. constellatus, S. anginosus, S. internediusに 細分類された. 今回口腔内より分離される $S$. inter me'dius を起炎菌とし, 患者本人の職業との関連を示唆 される症例を経験したので報告する.

$$
\text { 症例 }
$$

患者：42歳, 男性.

職業：画科医。

主訴：右側胸部の腫脹・排膿。

既往歴：1998年10月，胃潰瘍，投楽治療，1999年 6 月, 左前腕部蜂窩織炎 (診療中の穿刺事故による). 1999 年 9 月，薬剤アレルギーにて内科入院加療，入院中に DLST (drug lymphocyte stimulation test : 薬剤リン パ球刺激試験）施行された。また従来よりペニシリン アレルギーあり.

家族歴：特記事項なし。

2004年11月22日受付 2005年4月20日採用

〈所属施設住所〉

テ 807-8555 北九州市八幡西区医生ヶ丘 1-1
現病歴：2000年 4 月中旬より特に外傷なく右肩関節 痛あり，同部の腫脹が始まる，徐々に右腋裔から側胸 部の腫脹が増強したため，4 月23日自ら $18 \mathrm{G}$ 注射針を 数力所刺入して内容除去を試みた。刺入部より血性朖 汁の排出あり，同時に創部が自潰した。ガーゼパッキ ングのまま経過，4 月27日自ら診療所の縫合針と絧采 を用いて 7 針縫合４ 4 月28日創より大量の排膿あり， アレルギーにて入院歴のある当院第 1 内科を受診, 同 日当科紹介受診となった。

入院時現症: 意識清明, 体温 $37.1^{\circ} \mathrm{C}$, 脈拍 $102 /$ 分, 整, 血圧 $122 / 60$, 眼瞼結膜：貧血様, 右腋窝から前胸 部側胸部にかけて压痛を伴う発赤, 腫脹あり。触診上 握雪感あり．同部に約 $10 \mathrm{~cm}$ および $2 \mathrm{~cm}$ にわたる絧系 による不整な縫合創あり。一部は離開し, 血性價汁の 排出を認める。異臭なし(図 1 )。右側腹部に负術施行 (2000年 4 月 8 日頃)による $7 \mathrm{~mm}$ 大 3 力所の熱傷洀 痕あり。硬結と周囲の腫脹認める。压痛なし，左鼠径 部にリンパ節様腫脹 $2 \times 1 \mathrm{~cm}$ 大あり.

入院時検查成績：WBC $26,800 / \mu 1, C R P-Q 3.4$ $\mathrm{mg} / \mathrm{dl}, \mathrm{Hb} 6.9 \mathrm{~g} / \mathrm{dl}$, TP $5.9 \mathrm{~g} / \mathrm{dl}$, Alb $3.1 \mathrm{~g} / \mathrm{dl}, \mathrm{BS} 156$ $\mathrm{mg} / \mathrm{dl}$, AST 18IU/l, ALT 23IU/l.

単純 $\mathbf{X}$ 線撮影（軟部条件）所見：右腋窝加ら前胸部 


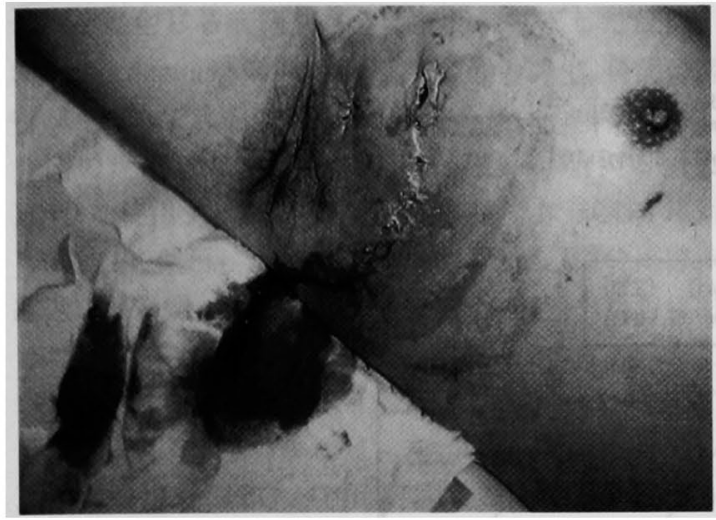

図 1 入院時外貌写真：右腋窝から前胸部側胸部にかけ

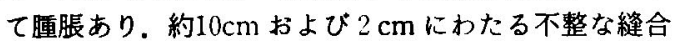
創あり。創緑より血性朖汁の排出を䜑める。

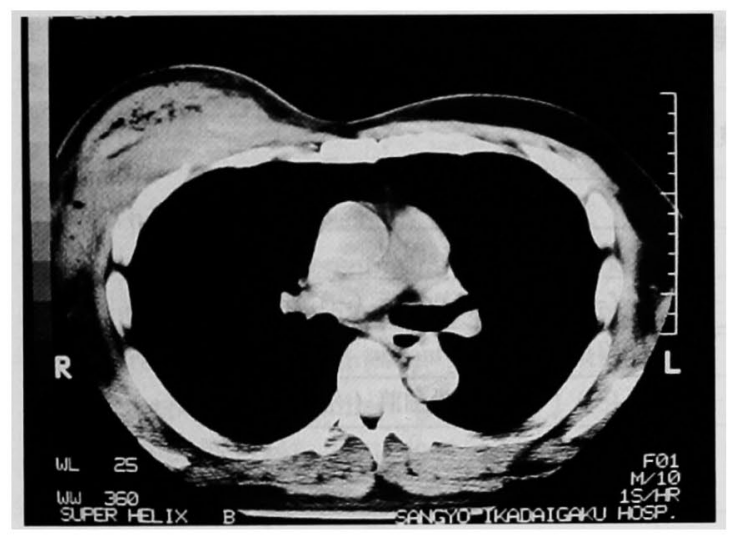

図 2 胸部単純 CT：右前胸部の皮下，胸筋間にガス像を 認める。

にかけて点状および線状ガス像を認める。

胸部 CT 所見：右腋窝から前胸部の皮下, 大胸筋・小 胸筋間, 広背筋内側にガス像を認める。筋膜, 軟部組 織の混濁を認める(図 2 )。

入院後経過：臨床経過，所見，レントゲン,CTより ガス壞疽あるいは壊瘨性筋膜炎と診断し, 直ちに全身 麻酔下に切開ドレナージ手術を行った。

手術所見：自潰創を含み乳輪頭側に孤状切開．大胸 筋前面は壊死した筋膜と膿を混した凝血塊に覆われて いた．異臭はなし，デフリードマン施行．壊死は上方 は鎖骨下，内側は胸骨外縁，下方は乳輪直下，外側は 中腋窝線に達しておう，大胸筋後面と小胸筋との間に も血性膿性の排液を認め, 広背筋内側も後腋窝線まて 同様にデブリードマン施行，右側腹部の负術瘵痕部に

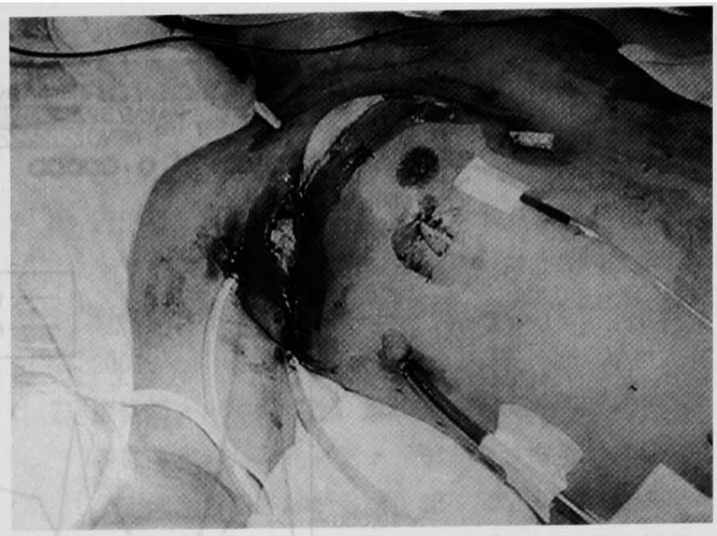

図 3 術後外貌写真 : 腋窝, 大胸筋小胸筋間, 後背筋内側, 皮下にドレーンを置いた。

も切開を加える。筋膜は黄茶色で肥厚し，浮腫様であ るが，膿汁の貯留は認めず．左鼠径部のリンパ節腫脹 様病変は，リンパ節でなく，皮下の硬結であった，浮 腫様, 色調不良であるか䐬汁の貯留は認めず。術後外 貌写真（図 3）の様にドレーンを置き，手術を終了.

術後経過：創処置により徐々に消炎，高圧酸素療法 (hyperbaric oxygen therapy, 以下 HBO) (2.5ATA, 60 分）を併用した。入院中の 5 月15日にもDLST 施行 し，加療に使用する可能性の高い薬剂を検討した．第 36病日にデブリードマン，二次縫合を行い，第56病日 に退院となった，症例経過図を図 4 k，細菌検査の経 過を表 1 に示す。

\section{考察}

今回病巣より検出された Streptococcus intermedius は，ガス産生性 Streptococcus として知られる S. mil leri が近年細分類されたもので'2)，他の 2 つは S. constellatus, S. anginosus ${ }^{3)}$ であ. S. milleri グループは, 口腔内, 腸管, 胵から分離され,ガス買疽, myonecrosis の原因菌として報告される゙，またS．internedius は 口腔インプラント感染巣から分離される菌である5). Streptococcusはガス壊疽, 壊瘨性筋膜炎の原因 菌(4) ${ }^{4)(8)}$ として重要であり，基礎疾患のない若年者の口 底部ガス蜂窝織炎の報告もあり ${ }^{9}$, 歯科・口腔外科領域 では特に注意を要する。

本症例は薬剤アレルギーを有する歯科医に生じたガ 不買瘨症例である。もともとの膿瘍の起炎菌は不明で あるが, 当初よりガス産生菌であった可能性もある. また患者自らが歯科診療所の器材を用いて行った縫合 創処置によって，ドレナージを妨げ，嫌気条件をつく 


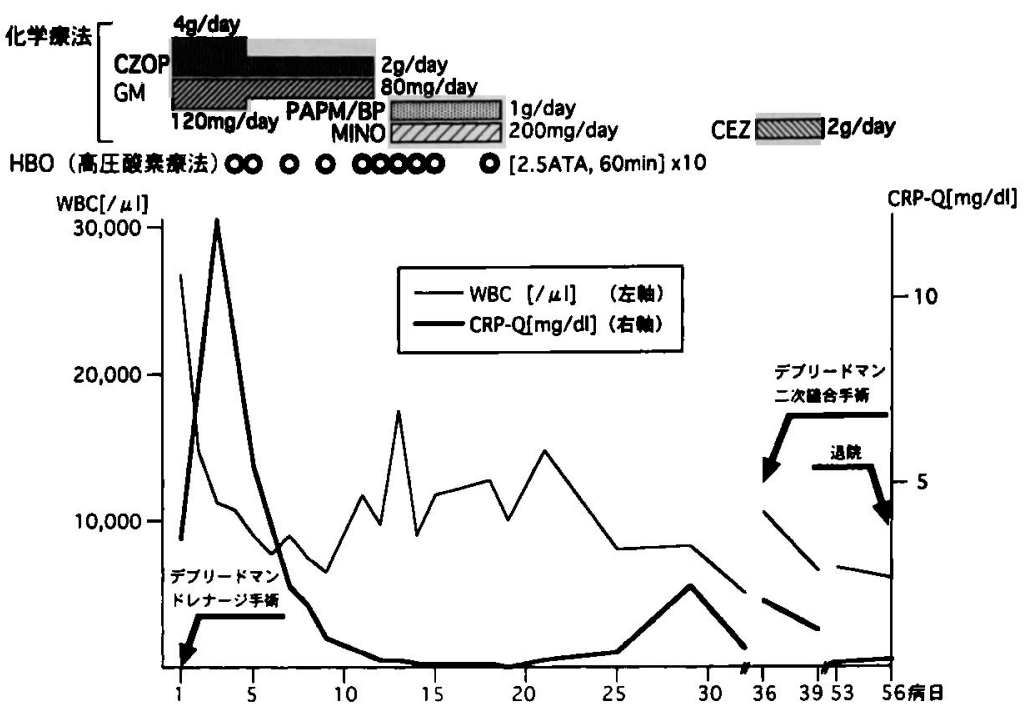

図 4 症例経過図

表 1 細菌検查所見

\begin{tabular}{|c|c|c|c|c|c|}
\hline \multirow{2}{*}{ 取月日 } & \multirow{2}{*}{ 病日 } & \multicolumn{2}{|r|}{ 一般湅菌検查 } & \multicolumn{2}{|r|}{ 嫌気性菌検査 } \\
\hline & & 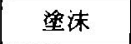 & 同定 & 咥沫 & 同定 \\
\hline$+/ 28$ & 1 & $G P C \cdot(t)$ & S. intermedius $(++)^{* *}$ & $(-)$ & 嫌気性細菌（一) \\
\hline $4 / 30$ & 3 & & - & $\mathrm{GPC}(+)$ & S. intermedius $(++)$ \\
\hline $5 / 1$ & 4 & $(-)$ & S. intermedius $(+)$ & $(-)$ & 嫌気性細菌 (-) \\
\hline $5 / 4$ & 7 & $(-)$ & $\begin{array}{c}\text { S. species (+) } \\
\text { (增菌培算) }\end{array}$ & $(-)$ & 嫌気性細菌（一） \\
\hline $5 / 10$ & 13 & $(-)$ & 発育を認めず & & \\
\hline $5 / 29$ & 32 & $(-)$ & 発育を認めず & & 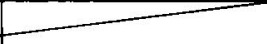 \\
\hline
\end{tabular}

*GPC：グラム陽性球菌, **S：Streptococcus

り出し, 器具に付着していたS. intermedius が增殖し た可能性もあるまた，患者からの聴取によると，既 往歴にもあるように，歯科診療中に自分の上腕などを 穿刺する事故はありうるとのことであるが，最初の腋 窝の膿瘍形成は, 効き腕側の腋窝に生じており, 診療 中の事故によって生じたとは考えにくい.

ガス壊疽は本邦においては，古典的な「外傷後に生 じるクロストリジウム単独感染」から「compromized host に生じる非クロストリジウム性混合感染」へと移 行してきた ${ }^{10)}$. 本症例も薬剤アレルギーで入院歴があ り，アレルギーが生じると CRP-Q $10 \mathrm{mg} / \mathrm{dl}$ 前後を推 移する病歷があった。内科入院時に, DLST が施行さ れており,アレルギーの生じない安全な抗生猎 (cefozopran, gentamicin, panipenem, minocycline)
使用することができた。そのため炎症を評価する方法 としてWBC，CRP が活用でき，臨床的に有用であっ た.二次縫合のため用いた cefazolinについては, 今回 入院中に 2 度目の DLST を行って陰性を確認した。ア レルギーの生じない薬郕を選択するために, DLST は 非常に有効であった。

$\mathrm{HBO}$ は古典的にはクロストリジウム性ガス壊疽 (clostridial gas gangrene, CGG) に有効であり, 非 クロストリジウム性ガス壞疽 (nonclostridial gas gangrene, 以下 NCGG) に対して無効であるとされてい

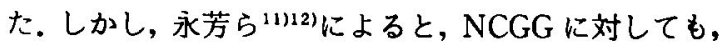
高圧下における酸素の静菌効果, 白血球領食能の活性 化, 浮腫の改善および局所循䍙の改善などによる組織 修復作用が期待されるため, HBO は有効という.また 
体幹部に生じる症例や, 免疫機能の低下した症例, Streptococcus 感染例ては, 全身状態の悪化, 炎症の進 行がきわめて急速であることが多い(13)，とされるため， 今回の症例では, 細菌㭘査の結果が判明する前に HBO を使用することとした，自験例でも NCGG に対 し HBO を使用した例を経験しているが, HBO が臨床 経過に悪影響を与えた印象はない4。諸家の報告にお いても NCGGに対して, 可能ならば HBO を使用して いく傾向にあり，相対的適応ありとする見解が優勢で ある6(14)15!。症例が少なく, evidenceがないため, NCGG の場合 $\mathrm{HBO}$ が利用可能な施設であれば行う が，転送してまで行う必然性はないというのが現実的 見解と考えられる。

\section{結語}

薬剂アレルギーを基礎に持つ患者の, 職業との関係 を示唆されるガス壊瘨症例を経験した。効果的な治療 薬選定に DLST が役立ち, 開放ドレナージ・抗生剤・ 高圧酸素療法にて加療した。

\section{文 献}

1) Whiley RA, Fraser H, Hardie JM, et al: Phenotypic differentiation of Streptococcus intermedius, Streptococcus constellatus, and Streptococcus anginosus, strains within the "Streptocuccus milleri group". J Clin Microbiol 28 : 1497-1501, 1990

2) Whiley RA, Beighton D : Emended descriptions and recognition of Streptococcus constellatus, Streptococcus intermedius, and Streptococcus anginosus as distinct species. Int J Syst Bacteriol $41: 1-5,1991$

3）奥田 剛, 原 浩貴, 今手祐二他：綐隔まで進展 した頸部ガス壊疽症例. 日耳感染症研会誌 $19: 30-34,2001$

4）岡崎啓介, 武田和久, 佐古達彦他：体幹部に進展
したガス䘫疽の 1 症例. 臨外 $49: 363-366,1994$

5) Tanner A, Maiden MFJ, Lee $K$, et al : Dental implant infections. Clin Infect Dis 25 (Suppl 2) : S213-217, 1997

6) 吉田真一, 佐藤展之, 吉田行雄他：下肢非クロス トリジウム性ガス壊疽の 2 例一特に高圧酸素療法 有効例を中心に一. 中部整災誌 $44: 1137-1138$, 2001

7）金子裕之，片倉 玄，深田健治他：結腸癌末期患 者に発症した非クロストリジウム性頸部ガス壇疸 の1例。日口腔診断会誌 $13: 505-509,2000$

8）平田孝夫，金子秀一，小泉有美眻他：B 群連鎖球 菌による壊死性筋膜炎の 1 救命例。日集中治療医 会誌 $9: 121-126,2002$

9）坂井陳作，徳永有紀，佐藤谆一地：基碳疾患のな い若年者に発症した口底部非クロストリジウム性 ガス蜂䆚織炎の 1 例. 日腔外会誌 $46: 599-$ 601,2000

10）内山元昭：ガス壊疸症例の検討，共済医報 44 ： $15-22,1995$

11）永芳郁文，田村裕昭，川嶌眞人：糖尿病性ガス壊 㾴に対する高気圧酸素療法。日骨関節感染研会誌 $15: 82-85,2001$

12）永芳郁文, 川嶌直人：ガス壊瘨, 破傷風の治療。 骨・関節・勒帯 $15: 525-532 ， 2002$

13）西出和幸, 杉本 佩：非クロストリジウム性ガス 壊瘨。救急医 $10: 833-844,1986$

14）森永伊昭，木村政一，植口和東：非クロストリシ ウム性力不壊㾴一自験25例と報告例の検討一。日 骨関節感染研会誌 $12: 12-16,1998$

15）藤田聡志，下田哲司，藤原 淳他：非クロストリ ジウム性ガス壊疽の 7 例。関東整災外会誌 28 ： $72-76,1997$ 


\title{
A CASE OF GAS GANGRENE IN A DENTIST CAUSED BY STREPTOCOCCUS INTERMEDIUS INFECTION
}

\author{
Keisuke OKAZAKI, Kentaro MATSUMOTO, Kohji OKAMOTO, \\ Tetsumi KONISHI, Naoki NAGATA and Hideaki ITOH
}

Department of Surgery I, University of Occupational and Environmental Health

We report a case of nonclostridial gas gangrene in a dentist caused by $S$. intermedius that was isolated from the oral cavity. A 42-year-old male dentist was admitted in April 2000, complaining of high fever and severe pain in the right axilla and chest. Pain and swelling started two weeks before without history of trauma and there was suppurative discharge five days before admission. The patient incised and drained his axilla and stitched the wound by himself using instruments in his dental office. On admission his axilla and front chest were swollen with palpable crepitations of the skin. He was diagnosed to have gas gangrene by X-ray, CT-scan and laboratory findings. He was treated with surgical debridement of necrotic tissue immediately. Antibiotics, that were negative on DLST (Drug Lymphocyte Stimulation Test) were administered intravenously. He also received hyperbaric oxygen therapy (2.5 ATA, $1 \mathrm{hr}, 10$ times). After a secondary closure of the wound was performed, the patient was discharged without any further complications 55 days after his initial operation. S. intermedius is one of the members of the Streptococcus milleri group. S. milleri group are indigenous bacteria separated from the oral cavity, intestine and vagina and are reported as a possible pathogen of the gas gangrene or myonecrosis. In this case, $S$. intermedius infection is recognized as an occupation related disorder. 